\title{
FOLLOW-UP OF PSYCHIATRIC PATIENTS RETURNED TO DUTY
}

\author{
Lieutenant Colonel L. J. F. WARNANTS, L.R.C.P., \& S.I., D.P.M., R.A.M.C. \\ Surgeon Commander D. H. MARJOT, M.B., B.Ch., D.P.M., R.N. \\ Royal Victoria Hospital, Netley
}

A follow-up of Royal Naval and Royal Marine patients referred to the Psychiatric Department at the British Military Hospital, Singapore in 1964 has been published elsewhere (Marjot and Warnants, 1967).

The present study is a follow-up survey. of United Kingdom-based British Army patients seen at Singapore in the same year. While the series consists of a smaller number of patients, the period of follow-up is longer i.e. 3 years. As with Royal Naval personnel, only those patients who suffered from major or psychotic illness were evacuated to the United Kingdom.

The patients under review had complained of problems involving unrealistic emotional responses towards unpleasant events, but did not suffer from any pathological impairment of their capacity for learning to choose between alternative courses of action. The relationship between physiological manifestations of emotion and unpleasant experience was explained to them, and the ways whereby emotional arousal affects cognitive functions were clarified. The confidence of some individuals was developed by teaching them a means of controlling emotional events by self-relaxation. Once this skill became automatic, and thus instantaneously available, they became able to exercise a beneficial influence upon the subsequent course of events. Where necessary, problems affecting their management were discussed with their Commanding Officers.

Ninety-six United Kingdom-based British Army personnel, with a mean age of 25 years, were referred for psychiatric assessment in Singapore in 1964. All but three members of the Women's Royal Army Corps and one nurse in Queen Alexandra's Royal Army Nursing Corps were male.

Twenty-two patients, all of them male, were found unfit to remain in Far East Land Forces, and were evacuated to the United Kingdom with the following diagnoses (Table 1):

Table I

Diagnoses of twenty-two patients evacuated to the United Kingdom

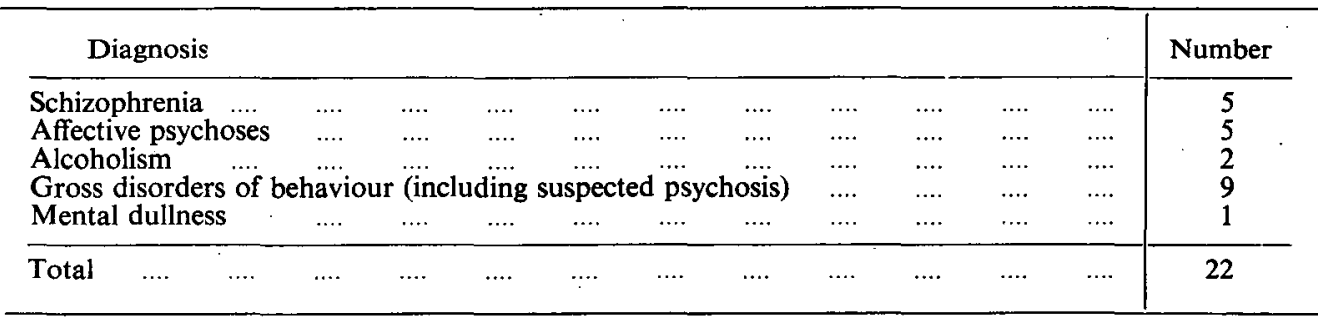

Of the 74 patients who were returned to duty without any change of their PULHEEMS Employment Standard, six have not been traced, owing to incorrect transcription of personal numbers on their documents.

The following information was retrieved from an examination of the medical records of the remaining 68 patients (Table II): 
Table II

Follow-up of sixty-eight patients

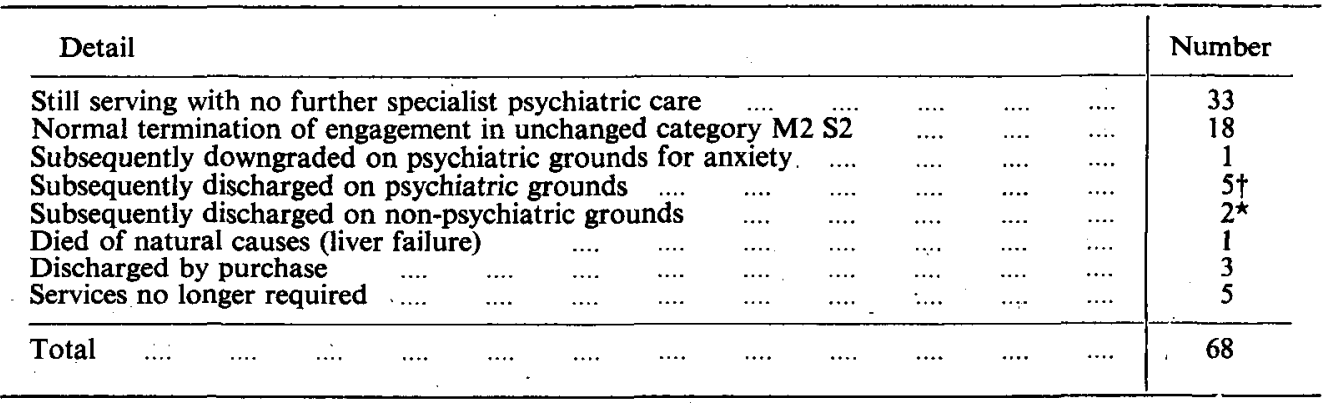

Diagnostic breakdown of medical discharges

\begin{tabular}{|c|c|c|c|}
\hline $\begin{array}{l}\text { †Alcoholism } \\
\text { Homosexuality } \\
\text { “Headaches" } \\
\text { Anxiety state }\end{array}$ & $\begin{array}{l}2 \\
1 \\
1 \\
1\end{array}$ & $\begin{array}{l}{ }^{\star} \text { Chonoro-sarcoma of Ilium } \\
\text { Chronic bronchitis and emphysema }\end{array}$ & $\begin{array}{l}1 \\
1\end{array}$ \\
\hline
\end{tabular}

\section{Discussion}

It will be seen that none of the patients returned to duty subsequently developed a psychotic illness. Of those later discharged on psychiatric grounds, two were alcoholic. A similar experience is reported by Marjot and Warnants (1967). Alcoholism is a significant reason for re-referral to a psychiatrist. Like other problems which are the outcome of bodily reaction to abuse, such as smoking, problems arising from an excessive consumption of alcohol become more serious with the passage of time. Patients referred with such problems therefore should always be very carefully assessed.

Attempts to employ psychiatric channels in order to dispose of "difficult" soldiers were resisted. That the form of discharge from the Services does not matter once a man has been adjudged of little or no use to the Service is often asseverated. If such a view was valid, there would be no need for categories! Ethical difficulties arise, including the handicap which a man may face by being classified as mentally disordered. The Administration may be prevented from dealing appropriately with neglected areas of man-management, and a need to re-examine recruitment and selection procedure may remain concealed.

Policies affecting the downgrading, evacuation and discharge of patients on psychiatric grounds vary widely. Marren (1956) drew attention to the importance of an "organized, integrated and effective" psychiatric policy directed at conservation of man power. The effects of such a policy are dramatically reflected in the reversal of the ratio of non-psychotic to psychotic evacuations from Korea which changed from 20:1 in the fourth quarter of 1950 to $1: 7$ for the whole of 1952. Of those not evacuated in 1952 , between 80 and 90 per cent returned to combat units.

The authors are of the opinion that their findings support a policy of returning Servicemen to duty in the absence of psychotic illness.

\section{REFERENCES}

MARJOT, D. H. aud WARNANTS, L. J. F. (1967) J. roy. nav. med. Serv. 53, 89

MARREN, J. J. (1956) U.S. armed Forces med. J. 7, 715 